\title{
Meiotic behavior of economically important plant species: the relationship between fertility and male sterility
}

\author{
Maria Suely Pagliarini
}

Departamento de Biologia Celular e Genética, Universidade Estadual de Maringá, 87020-900 Maringá, PR, Brasil.

E-mail:mspaglia@dbc.uem.br

\begin{abstract}
Meiosis is an event of high evolutionary stability which culminates in a reduction of chromosome number. The normal and harmonious course of meiosis ensures gamete viability. The cytologic events of gametogenesis are controlled by a large number of genes that act from premeiotic to postmeiotic mitosis. Mutations in these genes cause anomalies that may impair fertility, and many abnormalities affecting plant fertility or causing total male sterility have been detected during the evaluation of meiotic behavior in some species. Some of these abnormalities have been frequently described in the literature, while others have not been previously reported. The most frequent abnormalities found in the species analyzed were irregular chromosome segregation, cytomixis, chromosome stickiness, mixoploidy, chromosome fragmentation, syncyte formation, abnormal spindles, and failure of cytokinesis. Uncommon abnormalities, such as chromosome elimination during microsporogenesis, were found in one species. Original meiotic mutations affecting different steps of meiosis were also observed in these species, especially in maize, Paspalum and soybean. Some mutants present characteristics that may be exploited successfully in breeding programs because they cause total male sterility.
\end{abstract}

\section{INTRODUCTION}

Meiosis is a seemingly paradoxical process in which universality and uniqueness are harmoniously combined. All organisms, irrespective of their evolved complexity, meiotically reduce the chromosome number at the start of sexual reproduction, compensating for fertilization and maintaining the diploid chromosome set from generation to generation (Golubovskaya, 1979).

Micro- and megasporogenesis comprise three sequential stages that culminate with gamete formation, that is pre-meiosis, meiosis and post-meiosis, which are controlled and coordinated by a diversity of genes. Meiosis, in addition to being the stage of longest duration, is also the stage that consumes the most cellular energy and is controlled by a larger number of genes than the other stages. Although consisting of individual components, suggesting independent hierarchical gene control at each step, meiosis is a highly coherent integrated process, although the steps may be changed by the presence of mutant genes resulting in abnormal meiotic products that prevent ga- mete formation and impair plant fertility. Similarly, preand post-meiosis may also be affected by the action of mutant genes, but these events, in contrast to meiosis, are controlled by a relatively small number of genes. The major mutations causing male sterility are post-meiotic, and sterile male mutants provide a potential starting point for the genetic and molecular investigation of anther and pollen development in higher plants. In addition, such mutants have often been investigated for their applications to plant breeding, and in particular for their potential use in the production of hybrid seed (Kaul, 1988). Seventeen years ago, the Laboratory of Plant Cytogenetics of the State University of Maringá (PR, Brazil) started some studies aimed at the evaluation of meiotic behavior in plant species economically important to Brazil. About 50 species were analyzed and, in general, most of them presented some problem related to seed production.

\section{MATERIAL AND METHODS}

Various species were investigated, including those of agronomic value (Zea mays, Brassica napus, Brassica campestris, Glycine max, Saccharum officinarum, Cedrela fissilis, Hevea brasiliensis, Euphorbia heterophylla, Vitis vinifera, Avena sativa and more than 30 Paspalum species), medicinal value (Centella asiatica, Ochna sp., Pilocarpus pennatifolius, Aloysia lycioides, Cissus sp.), and ornamental value (Chlorophytum comosum, Thunbergia mysorensis, Aptenia cordifolia, and Boungainvillea). Species of agronomic value (usually represented by commercial cultivars, inbred lines or accessions from germplasm collections) were donated by private breeding companies or governmental enterprises involved in plant breeding, especially the national research centers for specific crops (Embrapa). Medicinal species were collected in the Medicinal Garden of the State University of Maringá, whereas those of ornamental value were collected in Maringá city.

The number of plants analyzed in each study was variable, depending on the objectives and the availability of the material. For all species, the methodology employed for meiotic analysis was the same. Flower buds in the ideal stage for meiotic studies were fixed in 3:1 alcohol:acetic acid, transferred to $70 \%$ alcohol and stored under refrigeration. Slides were prepared by the squash technique followed by 
staining with $1 \%$ propionic carmine. Starting from the pachytene, all meiotic phases were analyzed. When necessary and possible, pollen viability was also tested.

\section{RESULTS AND DISCUSSION}

Maize is the crop most frequently analyzed in our laboratory, with studies having been started twenty years ago to assess the genetic control of chiasma frequency (Pagliarini, 1980) which we showed to be under polygenic control, suggesting that inbred lines may present differences in chiasma frequency after inbreding. This fact was later confirmed by Aguiar-Perecin et al. (1984), who showed that a low chiasma frequency leads to the appearance of univalent chromosomes. In order to correlate chiasma frequency with combining ability many inbred lines of maize were analyzed (Pagliarini, 1983, 1989; Pagliarini et al., 1986), and in all cases there was a correlation between the two traits, showing that univalents lost during the meiotic process impair pollen fertility and seed production.

The most common meiotic abnormality found was irregular chromosome segregation, characterized by precocious chromosome ascension and laggards. This irregularity was widely observed in inbred lines of maize (Pagliarini, 1983, 1989; Pagliarini et al., 1986; Defani-Scoarize et al., 1995a,b, 1996), Chlorophytum comosum (Pagliarini et al., 1993), sugarcane (Pagliarini et al., 1990), Bougainvillea (Adamowski et al., 1996), Aloysia lycioides (CorazzaNunes et al., 1993, 1995), Hevea brasiliensis (Pagliarini et al., 1992a), Ochna sp. (Pagliarini et al., 1992b), Pilocarpus pennatifolius (Pagliarini and Pereira, 1992), Aptenia cordifolia (Pagliarini, 1990a), Centella asiatica (Consolaro and Pagliarini, 1996a), Brassica napus and B. campestris (Souza et al., 1997), and in many Paspalum species (Freitas et al., 1997; Adamowski et al., 1999). The causes of this abnormality can be diverse. Univalent chromosomes at diakinesis or metaphase I may result from low chiasma frequency, precocious chiasma terminalization or by the presence of asynaptic or desynaptic genes in prophase I (for review, see Gottschalk and Kaul, 1980a,b; Koduru and Rao, 1981). Irrespective of their origin the meiotic behavior is always the same, with univalents showing precocious ascension at metaphase I or remaining as laggards at anaphase I. In both cases they may originate micronuclei at telophase I and in meiosis II. In all species in which irregular chromosome segregation occurred a correlation between this characteristic and pollen fertility or seed production was observed. Another more rare segregational abnormality observed was non-congressed bivalents at the equatorial plate in metaphase I, only found in Chlorophytum comosum (Pagliarini et al., 1993), Glycine max (Bione et al., 1999) and Avena sativa (Baptista-Giacomelli, 1999).

Chromosome transfer from cell to cell through cytoplasmic connections, a phenomenon known as cytomixis, has been observed in Pilocarpus pennatifolius (Pagliarini and Pereira, 1992), Centella asiatica (Consolaro and
Pagliarini, 1995), Brassica napus and B. campestris (Souza and Pagliarini, 1997), maize (Caetano-Pereira and Pagliarini, 1997), and Glycine max (Bione et al., 1999). Although cytomixis has been reported in several plant species, its origin is not clear, but among the factors thought to cause it are the influence of genes, abnormal cell wall formation during premeiotic divisions, chemicals, pathological conditions, herbicides, radiation, temperature, mechanical injury, hybridization and polyploidy. The causes of cytomixis in the species cited above were not identified, although the affected plants were grown under the same environmental conditions as normal ones. Although the role of cytomixis in plant evolution is considered an additional mechanism for the origin of aneuploidy and polyploidy, the deviation in chromosome number affects pollen fertility. In all the species investigated the number of cells showing cytomixis was low, although it, along with other cellular abnormalities, contributed to increased pollen sterility.

Chromosome stickiness was another abnormality observed in some plants, occurring in maize (Caetano-Pereira et al., 1995a), Centella asiatica (Consolaro and Pagliarini, 1996b), Brassica napus and B. campestris (Souza and Pagliarini, 1996) and Glycine max (Bione et al., 1999). Stickiness is characterized by chromosome clustering during any phase of the cell cycle. The phenotypic manifestation of stickiness in these species was highly variable, ranging from a mild phenomenon involving only a few chromosomes in the genome, to an extensive one involving the entire chromosome complement. Chromosome stickiness may be caused by genetic and environmental factors, and several agents have been reported to cause chromosome stickiness. In maize cultivated in Brazilian cerrado (Brazilian savanna) soils, where aluminum saturation is naturally high, Caetano-Pereira et al. (1995a) observed intense chromosome stickiness in microsporocytes, with inbred lines being more affected than hybrid lines, while in the other species, the results suggested that interactions between the plant genotype and the environment caused chromosome stickiness. In severe cases of stickiness, the lack of chromosome separation provoked the formation of single or multiple pycnotic nuclei which culminated in full chromatin degeneration. Depending on the intensity of chromosome stickiness, pollen fertility may be partial or totally affected. Although many studies have reported the occurrence of chromosome stickiness, the primary cause and biochemical basis of the phenomenon are unknown. Gaulden (1987) postulated that stickiness may result from the defective functioning of one or two types of specific nonhistone proteins involved in chromosome organization which are needed for chromosome separation and segregation. The altered functioning of these proteins is caused by mutation in the structural genes coding for them (hereditary stickiness) or by the direct action of mutagens (induced stickiness).

Chromosome fragmentation, chromosome degeneration, mixoploidy and cell fusion were also observed among 
the species investigated, especially in maize. Some inbred lines, single-cross and double-cross hybrids, cultivated in cerrado soils and in the south of the country, presented intense chromosome fragmentation (Caetano-Pereira et al., 1995b), closely resembling the chromosome shattering reported in the literature. The spontaneous appearance of this abnormality in plants is unusual, and previous descriptions have indicated that it was due to induction by radiation, sometimes associated with chemicals and agents known to be clastogenic and mutagenic (Cremer et al., 1981; Albanese, 1982; Cremer and Cremer, 1986). The chromosome fragmentation observed in maize microsporocytes may be associated with damaged of DNA repair mechanisms caused by genetic and/or environmental factors. This assumption is due to the fact that inbred lines from distinct locations, but of common origin, were much more affected than heterozygous genotypes, and the phenotypic expression of this abnormality was much higher when the lines were cultivated on acid soils. Mixoploidy also occurred in this group of genotypes (Caetano-Pereira et al., 1998a), and 13 genotypes out of 43 evaluated presented pollen mother cells with different levels of ploidy in the same anther, ranging from diploidy to octaploidy. In plants cultivated in southern Brazil all cells with altered ploidy levels presented nuclear fusion, i.e., all chromosomes shared the same nucleus, but in plants cultivated in the center western region, in addition to this type of behavior for $4 n$ cells, other cells ( $4 n, 6 n$ and $8 n$ ) only showed cytoplasm fusion, with the nuclei remaining individualized. Although mixoploidy is widely reported in somatic tissues (for a review, see Nirmala and Rao, 1996), it is rare in anthers. Mixoploidy is often associated with the occurrence of polyploidy, hybridization, chemicals and, in same cases, it is genetically controlled. In the affected maize genotypes, the results suggest that the abnormality is under genotypic control. Mixoploidy is a cytogenetic event of great importance with practical and evolutionary implications. In higher plants lacking sexual reproduction, mixoploidy is a potential force in evolution, while in sexually propagated species, the chromosomal instability in reproductive tissue can produce gametes with variable chromosome numbers with the addition or loss of chromosomes and the formation of gametes that can produce aneuploids in subsequent generations which may present low fertility due to meiotic irregularities. In the maize genotypes affected by mixoploidy, unbalanced gametes side-by-side with normal ones cause impaired seed production. Also in this group, the majority of genotypes showed syncyte formation (Caetano-Pereira et al., 1998b); although for most genotypes the number of syncytes was small, in some it was higher. These syncytes must have resulted from cell fusion in premeiotic mitosis because they were observed from the early stages of meiosis. In another group of genotypes, also cultivated in cerrado soils, one inbred line showed syncyte formation (Caetano-Pereira $e t$ al., 1999). In some plants the syncytes showed progressive nuclear degeneration at the beginning of meiosis, produc- ing pycnotic micronuclei and incomplete cell cycle, while in other plants, meiosis was complete despite syncyte formation. Chromosome degeneration did not occur. Microspores and pollen grains anomalous in terms of shape, size and number of nuclei were observed, but the nuclei always remained separate, and we could not identify the cause of the abnormality. According to Nirmala and Rao (1996) cell fusion and chromatin degeneration may be caused both by environmental and genetic factors. Cell fusion, with or without chromatin degeneration, is considered to be a source of male sterility.

Abnormalities related to abnormal spindles and failure of cytokinesis were also frequently observed. Failure of cytokinesis was found in maize genotypes (DefaniScoarize et al., 1995a,b, 1996; Caetano-Pereira et al., 1998b) and in many accessions of Paspalum species (Pagliarini et al., 1999). In maize, two genes have been reported to disrupt cytokinesis, the $v a$ (variable sterile) gene (Beadle, 1932) and the $\mathrm{el}$ (elongate) gene (Rhoades and Dempsey, 1966), whereas the absence of cytokinesis has not been reported in Paspalum. The absence of cytokinesis in maize occurred at the end of both meiotic divisions, with a prevalence for meiosis II, and as a consequence, tetranucleate monads, binucleate dyads and triads were observed. In some dyads, a restitutional nucleus was formed. In Paspalum, only dyads and triads were formed, and there was no cytokinesis at the end of the first meiosis. Abnormal spindles were found in Thunbergia mysorensis (Pagliarini, 1990b), Ochna (Pagliarini et al., 1992b), Aloysia lyciodes (Corazza-Nunes et al., 1993), maize (Defani-Scoarize et al., 1995a,b, 1996; Caetano-Pereira et al., 1998b), and canola (Souza et al., 1999). Abnormal spindles are also an important meiotic irregularity, because depending on its shape, the spindle can rejoin or split the chromosome complement. Tripolar spindles, for example, produce $2 \mathrm{n}$ gametes, while multipolar spindles produce unbalanced and sterile gametes. The formation of $2 \mathrm{n}$ gametes has been investigated both for studies of evolution (Harlan and De Wet, 1975) and for breeding programs (Veilleux, 1985). Most species with a polyploid series have relied upon $2 \mathrm{n}$ gametes for the evolution of cultivated forms through sexual polyploidization. Breeders of many vegetatively propagated crops have been taking advantage of the occurrence of $2 \mathrm{n}$ gametes from wild diploid species for their cultivated polyploid crops through ploidy manipulation (Peloquin and Ortiz, 1992). Unilateral or bilateral polyploidization through the action of $2 \mathrm{n}$ gametes has been used for genetic improvement in many crops (Ortiz, 1997).

Chromosome elimination during microsporogenesis, an uncommon abnormality in plants, was detected in Paspalum subciliatum (Adamowski et al., 1998). Chromosome elimination occurs preferentially during the early stages of embryo development (Davies, 1974; Laurie and Bennett, 1986). Few reports have described this phenomenon during gametogenesis and many mechanisms have been described showing how the chromosomes can be eliminated 
(Singh, 1993; Fuge, 1997). The mechanism of elimination found in $P$. subciliatum has never been reported in any other species. In this species meiosis was normal until diakinesis, but starting at metaphase I meiosis was very peculiar because, while ten bivalents were clustered in the equatorial plate, the other ten were still dispersed in the cytoplasm. In anaphase I the chromosomes showed different abilities to migrate to the poles and while one genome reached the poles in telophase I, the laggard was in metaphase or anaphase and was engulfed by extra nuclei. In the second division, behavior of the chromosomes was the same, showing clear asynchrony in the cell cycle. The chromosomal behavior of this tetraploid $(2 n=40)$ accession suggests that it is an allotetraploid resulting from a cross between species whose chromosomes did not have the same rhythm in cell division. Chromosome elimination in interspecific hybrids is a powerful tool in breeding programs. Differential chromosome elimination has facilitated the production of additional lines, while total elimination of one genome permits the formation of haploids.

Meiotic division is characterized by the occurrence of a series of mechanical and biochemical phenomena of considerable complexity which culminate in the reduction of chromosome number. Extensive evidence obtained for different animal and plant species has demonstrated that each step of meiosis is genetically controlled (see Gottschalk and Kaul, 1974; Baker et al., 1976; Golubovskaya, 1979; Kaul and Murthy, 1985). Many meiotic mutants were found during these years, especially in maize (Albertsen and Phillips, 1981; Golubovskaya, 1989) and Arabidopsis thaliana (Dawson et al., 1993). Some of these mutants were known, whereas others had never been described before. Among well-known maize mutants are those displaying chromosome stickiness, failure of cytokinesis, syncyte formation, absence of first division, abnormal spindles, polymitotic division in microspores, etc. These mutants have been found and described by Defani-Scoarize et al. (1995 a,b, 1996) and Caetano-Pereira et al. (1995a, 1997, 1998b) along with some new maize mutants. Taschetto and Pagliarini (1993) have reported an unusual mutation affecting spindle formation in some plants of a double-cross hybrid, in which all meiotic steps were normal up to diakinesis, when disorganization started due to the lack of spindle formation. In the absence of a spindle the bivalents did not organize in the equatorial region, but remained scattered at random in the cytoplasm. The distance among bivalents was extremely variable, with the bivalents clustering into a few groups. Homologous chromosome segregation in anaphase I and sister chromatid segregation in anaphase II did not occur and meiosis went directly from diakinesis to the telophase, skipping the other phases, and telophases with the number of nuclei ranging from 3 to 10 were observed. As a consequence of these irregularities, microspore triads and polyads occurred producing sterile pollen grains of different sizes.

Another original meiotic mutation related to cell shape was found by Caetano-Pereira and Pagliarini (1996) in sev- eral inbred lines and hybrids cultivated in cerrado soils and which presented pollen mother cells with cytoplasmic projections similar to the pseudopods of amoebae. This abnormality occurred in all phases of meiosis, including pollen grains, but did not affect meiotic division or pollen fertility. Another original meiotic mutation was recently discovered by Caetano-Pereira and Pagliarini in which a premature and additional cytokinesis occurred in metaphase I, sometimes fractionating the genome. Despite this premature cytokinesis, normal cytokinesis occurred at the end of the first and second division. At the end of the first division, telophase I was represented by a tetrad, and at the end of the second division, telophase II was represented by a polyad, generally with microspores of different sizes.

Another original meiotic mutation was described in Paspalum regnellii by Pagliarini et al. (1998), which, in many aspects, is similar to that described by Taschetto and Pagliarini (1993) in maize. In the P. regnellii mutant there was spindle formation with the bivalents arranged at the equatorial plate as in normal metaphase I, but the spindle fibers did not converge towards the poles, instead there was degeneration of spindle fibers at the end of metaphase I and chromosome segregation did not occur, with the bivalents remaining scattered at random in the cytoplasm and remnants of chromosome fibers could be seen close to the centromere during this stage. In telophase I the bivalents gave rise to micronuclei with an extremely wide variation in number and size. With the absence of spindles in the second meiosis, metaphase and anaphase II were not observed. Second cytokinesis occurred in prophase II cells after the occurrence of the first cytokinesis. The final product of meiosis was completely abnormal, with a predominance of polyads with microspores of different sizes that resulted in abortive pollen grains. Also in Paspalum, an unidentified accession (BRA-014176) presented a sticky mutation that affected all meiotic phases, impairing chromosome segregation and reducing pollen fertility.

Some meiotic mutants present characteristics that may be successfully exploited in breeding programs, among which are those that cause male sterility in which male gametophytic function is prevented although the potential for female reproduction remains. Among the meiotic mutants identified some caused total male sterility. The maize mutant identified in a double-cross hybrid by Taschetto and Pagliarini (1993) was totally male sterile and its discovery led the breeders to remove it from the breeding program. In the last year, we began to analyze male sterile Brazilian lines of soybean and observed some interesting mutations. One line showed normal meiosis up to telophase II, when some irregularities started to occur, such as total or partial failure of cytokinesis, irregular cell shape and cell degeneration resulting in microspore degeneration in the tetrad and total pollen sterility. In another line meiosis was completely normal until tetrad formation, but the microspores isolated from the tetrad did not undergo total transformation into pollen grains. During pollen development, differentiation 
was affected, culminating in total sterility. In another soybean line the mutation affected prophase I, causing chromosome asynapsis which affected all meiotic phases, producing a polyad with many microcytes and sterile pollen. Although some meiotic mutants causing male sterility have been described in American soybean lines (Palmer et al., 1978, 1980; Albertsen and Palmer, 1979; Skorupska and Palmer, 1989), the mutants found in the Brazilian lines are original and are being tested for use in hybridization breeding programs.

\section{ACKNOWLEDGMENTS}

The author is grateful to the undergraduate and graduate students who have been part of the laboratory during the past few years. She is also grateful to Neide Silva for invaluable technical assistance.

\section{RESUMO}

A meiose é um evento de alta estabilidade evolucionária que culmina na redução do número de cromossomos. O curso normal e harmonioso da meiose garante a viabilidade gamética. Os eventos citológicos da gametogênese são controlados por um grande número de genes que atuam desde as mitoses pré-meióticas até as pós-meióticas. Mutações nestes genes causam anomalias que podem afetar a fertilidade. Durante a avaliação do comportamento meiótico em algumas espécies de plantas, muitas anormalidades que afetaram a fertilidade ou causaram total machoesterilidade foram detectadas. Algumas das anormalidades encontradas já eram descritas na literatura, enquanto outras eram totalmente desconhecidas. As anormalidades mais freqüentes nas espécies analisadas foram segregação irregular de cromossomos, citomixia, aderências cromossômicas, mixoploidia, fragmentação cromossômica, formação de sincícios, fusos anormais e falta de citocinese. Eliminação de cromossomos, uma anormalidade meiótica rara, foi observada em uma espécie de Paspalum. Mutantes meióticos nunca antes descritos, afetando diferentes passos da meiose, foram observados em algumas espécies, especialmente em milho, soja e Paspalum. Alguns mutantes apresentam características que podem ser exploradas com sucesso em programas de melhoramento, pois causam total macho-esterilidade.

\section{REFERENCES}

Adamowski, E.V., Pagliarini, M.S. and Valva, F.D. (1996). Avaliação do comportamento meiótico em Boungainvillea sp. (Nyctaginaceae) de diferentes regiões do Brasil. Rev. Unimar 18: 403-412.

Adamowski, E.V., Pagliarini, M.S. and Batista, L.A.R. (1998). Chromosome elimination in Paspalum subciliatum (Notata group). Sex. Plant Reprod. 11:272-276.

Adamowski, E.V., Pagliarini, M.S. and Batista, L.A.R. (1999). Chromosome number and microsporogenesis in Paspalum maritimum (Caespitosa group). Braz. Arch. Biol. Tecnol. 42: (in press).

Aguiar-Perecin, R., Pagliarini, M.S. and Villamizar, N.R. (1984). Aspectos do controle genético da formação de quiasmas em milho. In: Tópicos de Citogenética e Evolução de Plantas (Aguiar-Perecin, M.L.R., Martins, P.S. and Bandel, G., eds.) Sociedade Brasileira de Genética, Ribeirão Preto, SP, pp. 111-123.

Albanese, R. (1982). The use of fertilized mouse eggs in detecting potential clastogens. Mut. Res. 97: 315-326.

Albertsen, M.C. and Palmer, R.G. (1979). A comparative light and electron- microscopic study of microsporogenesis in male sterile $\left(m s_{l}\right)$ and male fertile soybeans (Glycine max (L.) Merrill). Am. J. Bot. 66: 253-265.

Albertsen, M.C. and Phillips, R.L. (1981). Developmental cytology of 13 genetic male sterile loci in maize. Can. J. Genet. Cytol. 23: 195-208.

Baker, B.S., Carpenter, A.T.S., Esposito, M.S., Esposito, R.E. and Sandler, L. (1976). The genetic control of meiosis. Annu. Rev. Genet. 10: 53135.

Baptista-Giacomelli, F.R. (1999). Avaliação do comportamento meiótico em variedades de aveia (Avena sativa) recomendadas para a região Sul., 1999. Master's thesis, Agronomia, Universidade Estadual de Maringá, Maringá

Beadle, G.W. (1932). A gene in Zea mays for failure of cytokinesis during meiosis. Cytologia 3: 142-155.

Bione, N.C.P., Pagliarini, M.S. and Toledo, J.F.F. (1999). Evaluation of meiotic behavior in some Brazilian soybean varieties. Genet. Mol. Biol. (in press).

Caetano-Pereira, C.M. and Pagliarini, M.S. (1996). Unusual shapes of maize microsporocytes. Nucleus 39: 107-110.

Caetano-Pereira, C.M. and Pagliarini, M.S. (1997). Cytomixis in maize microsporocytes. Cytologia 62: 351-355.

Caetano-Pereira, C.M., Pagliarini, M.S., Brasil, E.N. and Martins, E.N. (1995a). Influence of aluminum in causing chromosome stickiness in maize microsporocytes. Maydica 40: 325-330.

Caetano-Pereira, C.M., Taschetto, O.M., Defani-Scoarize, M.A. and Pagliarini, M.S. (1995b). Spontaneous chromosome fragmentation in maize microsporocytes. Cytologia 60: 297-301.

Caetano-Pereira, C.M., Defani-Scoarize, M.A. and Pagliarini, M.S. (1997). Spontaneous occurrence of genes mei afd and po in Brazilian maize population. Arq. Biol. Tecnol. 40: 271-277.

Caetano-Pereira, C.M., Taschetto, O.M., Pagliarini, M.S. and Brasil, E.M. (1998a). Spontaneous mixoploidy in maize anthers. Cytologia 63: 305309.

Caetano-Pereira, C.M., Defani-Scoarize, M.S., Pagliarini, M.S. and Brasil, E.M. (1998b). Syncytes, abnormal cytokinesis and spindle irregularities in maize microsporogenesis. Maydica 43: 235-242.

Caetano-Pereira, C.M., Pagliarini, M.S. and Brasil, E.M. (1999). Cell fusion and chromatin degeneration in an inbred line of maize. Genet. Mol. Biol. 22: 69-72.

Consolaro, M.E.L. and Pagliarini, M.S. (1995). Cytomixis in pollen mother cells of Centella asiatica (L.) Urban. Nucleus 38: 80-85.

Consolaro, M.E.L. and Pagliarini, M.S. (1996a). Meiotic behavior, pollen fertility and seed production in Brazilian populations of Centella asiatica (L.) Urban (Umbelliferae). Cytologia 61:375-381.

Consolaro, M.E.L. and Pagliarini, M.S. (1996b). Spontaneous chromosome stickiness in microsporocytes of Centella asiatica (L.) Urban (Umbelliferae). Cytologia 61: 57-61.

Corazza-Nunes, M.J., Pagliarini, M.S., Silva, I. and Silva, N. (1993). Polyploidy and its consequences in Aloysia lycioides (Verbenaceae). Arq. Biol. Tecnol. 36: 753-759.

Corazza-Nunes, M.J., Pagliarini, M.S., Silva, N. and Silva, I. (1995). Hexaploidy and fertility interrelationships in Aloysia lycioides (Verbenaceae). Arq. Biol. Tecnol. 38: 627-630.

Cremer, C. and Cremer, T. (1986). Induction of chromosome shattering by ultraviolet light and caffeine: The influence of different distributions of photolesions. Mut. Res. 163: 33-40.

Cremer, C., Cremer. T., Zorn, C. and Zimer, J. (1981). Induction of chromosome shattering by ultraviolet irradiation and caffeine: comparison of whole-cell and partial-cell irradiation. Mut. Res. 84: 331-348.

Davies, D.R. (1974). Chromosome elimination in interspecific hybrids. Heredity 32: 267-270.

Dawson, J., Wilson, Z.A., Aarts, M.G.M., Braithwaite, A.F., Briarty, L.G. and Mulligan, B.J. (1993). Microspore and pollen development in six male-sterile mutants of Arabidopsis thaliana. Can. J. Bot. 71: 629-638.

Defani-Scoarize, M.A., Pagliarini, M.S. and Aguiar, C.G. (1995a). Causes of partial male sterility in an inbred maize line. Cytologia 60:311-318.

Defani-Scoarize, M.A., Pagliarini, M.S. and Aguiar, C.G. (1995b). Evaluation of meiotic behavior in double-cross maize hybrids and their parents. Maydica 40: 319-324.

Defani-Scoarize, M.A., Pagliarini, M.S. and Aguiar, C.G. (1996). Meiotic behavior of inbred lines of maize (Zea mays L.). Nucleus 39: 10-18.

Freitas, P.M., Takayama, S.Y., Pagliarini, M.S. and Batista, L.A.R. (1997) 
Evaluation of meiotic behavior in polyploid accessions of Paspalum (Plicatula group). Nucleus 40: 47-52.

Fuge, H. (1997). Nonrandom chromosome segregation in male meiosis of a sciarid fly: elimination of paternal chromosomes in first division is mediated by non-kinetochore microtubules. Cell Motil. Cytoskeleton 36: 84-94.

Gaulden, M.E. (1987). Hypothesis: some mutagens directly alter specific chromosomal proteins (DNA topoisomerase II and peripheral proteins) to produce chromosome stickiness, which causes chromosome aberrations. Mutagenesis 2: 357-365.

Golubovskaya, I.N. (1979). Genetic control of meiosis. Int. Rev. Cytol. 58: 247-290.

Golubovskaya, I.N. (1989). Meiosis in maize: $m e i$ genes and conception of genetic control of meiosis. Adv. Genet. 26: 149-192.

Gottschalk, W. and Kaul, M.L.H. (1974). The genetic control of microsporogenesis in higher plants. Nucleus 17: 133-166.

Gottschalk, W. and Kaul, M.L.H. (1980a). Asynapsis and desynapsis in flowering plants. Asynapsis. Nucleus 23: 1-15.

Gottschalk, W. and Kaul, M.L.H. (1980b). Asynapsis and desynapsis in flowering plants. Desynapsis. Nucleus 23: 97-120.

Harlan, J.R. and De Wet, J.M.J. (1975). On Ö Winge and a prayer: the origins of polyploids. Bot. Rev. 41:361-390.

Kaul, M.L.H. (1988). Male Sterility in Higher Plants. Monogr. Theor. Appl. Genet. No. 10, Springer-Verlag, Berlin.

Kaul, M.L.H. and Murthy, T.G.K. (1985). Mutant genes affecting higher plant meiosis. Theor. Appl. Genet. 70: 449-466.

Koduru, P.K.R. and Rao, M.K. (1981). Cytogenetics of synaptic mutants in higher plants. Theor. Appl. Genet. 59: 197-214.

Laurie, D.A. and Bennett, M.D. (1986). Wheat x maize hybridization. Can. J. Genet. Cytol. 28: 313-316.

Nirmala, A. and Rao, P.N. (1996). Genesis of chromosomal numerical mosaicism in higher plants. Nucleus 39: 151-175.

Ortiz, R. (1997). Occurrence and inheritance of $2 \mathrm{n}$ pollen in Musa. Ann. Bot. 79: 449-453.

Pagliarini, M.S. (1980). Controle genético da freqüência de quiasmas em milho (Zea mays L.). Master's thesis, Genética e Melhoramento de Plantas, Escola Superior de Agricultura “Luiz de Queiroz”, Universidade de São Paulo, Piracicaba, SP.

Pagliarini, M.S. (1983). Correlação entre freqüência de quiasmas e capacidade de combinação em linhagens autofecundadas de milho (Zea mays L.): uma análise prévia. Rev. Unimar 5: 37-46.

Pagliarini, M.S. (1989). Avaliação da frequiência de quiasmas em milho (Zea mays L.) e suas implicações com a capacidade de combinação para a produção de grãos. Doctoral thesis, Genética e Melhoramento de Plantas, Escola Superior de Agricultura “Luiz de Queiroz”, Universidade de São Paulo, Piracicaba, SP.

Pagliarini, M.S. (1990a). Meiotic behavior and pollen fertility in Aptenia cordifolia (Aizoaceae). Caryologia 43: 157-162.

Pagliarini, M.S. (1990b). Instabilidade meiótica em Thunbergia mysorensis (Acanthaceae). Ciên. Cult. 42: 83-87.

Pagliarini, M.S. and Pereira, M.A.S. (1992). Meiotic studies in Pilocarpus pennatifolius Lem. (Rutaceae). Cytologia 57: 231-235.
Pagliarini, M.S., Miranda-Filho, J.B. and Aguiar-Perecin, M.L.R. (1986). Correlação entre freqüência de quiasmas e capacidade de combinação em linhagens autofecundadas de milho (Zea mays). Anais do XV Congresso Nacional de Milho e Sorgo. pp. 183-188.

Pagliarini, M.S., Silva, S.P. and Molinari, R. (1990). Análise meiótica em cultivares de cana-de-açúcar. Arq. Biol. Tecnol. 33: 283-293.

Pagliarini, M.S, Marques, J.R.B., Takayama, S.Y., Martinez, M. and Monteiro, W.R. (1992a). Poliploidia em seringueira. I. Análise do comportamento meiótico de alguns clones de Hevea brasiliensis. Rev. Unimar 14:25-35.

Pagliarini, M.S., Martinez, M. and Silva, I. (1992b). Some considerations on the cytology in Ochna sp. (Ochnaceae). Cytologia 57: 237-240.

Pagliarini, M.S., Pissinatti, M.B. and Silva, N. (1993). Chromosomal behaviour and seed production in Chlorophytum comosum (Liliaceae). Cytologia 58: 433-437.

Pagliarini, M.S., Freitas, P.M., Takayama, S.Y. and Batista, L.A.R. (1998). An original meiotic mutation in Paspalum regnellii. Sex. Plant Reprod. 11: 17-21.

Pagliarini, M.S., Takayama, S.Y., Freitas, P.M., Carraro, L.R., Adamowski, E.V. and Batista, L.A.R. (1999). Failure of cytokinesis and 2n gamete formation in Brazilian accessions of Paspalum. Euphytica 108: 129135.

Palmer, R.G., Winger, C.L. and Albertsen, M.C. (1978). Four independent mutations of the $m s_{l}$ locus in soybeans. Crop Sci. 18: 727-729.

Palmer, R.G., Johns, C.W. and Muir, P.S. (1980). Genetics and cytology of the $m s_{3}$ male-sterile soybean. J. Hered. 71:343-348.

Peloquin, S.J. and Ortiz, R. (1992). Techniques for introgressing unadapted germplasm to breeding populations. In: Plant Breeding in the 1990s (Stalker, H.T. and Murphy, J.P., eds.). CAB International, England, pp. 485-507.

Rhoades, M.M. and Dempsey, E. (1966). Induction of chromosome doubling at meiosis by the elongate gene in maize. Genetics 54: 505-522.

Singh, R.J. (1993). Plant Cytogenetics. CRC Press, Boca Raton.

Skorupska, H. and Palmer, R.G. (1989). Genetics and cytology of the $m s^{6}$ male-sterile soybean. J. Hered. 80: 304-310.

Souza, A.M. and Pagliarini, M.S. (1996). Spontaneous chromosome stickiness in canola. Nucleus 39: 85-89.

Souza, A.M. and Pagliarini, M.S. (1997). Cytomixis in Brassica napus var. oleifera and Brassica campestris var. oleifera (Brassicaceae). Cytologia 62: $25-29$

Souza, M.A., Pagliarini, M.S., Brandão Filho, J.U., Carraro, I.M. and Balbino, L.C. (1997). Evaluation of meiotic behavior in canola (Brassica napus var. oleifera and Brassica campestris var. oleifera) cultivars recently introduced in Brazil. Nucleus 40: 95-100.

Souza, A.M., Pagliarini, M.S. and Carraro, I.M. (1999). Abnormal spindles in second meiosis and its consequences in canola (Brassica napus and Brassica campestris). Braz. Arch. Biol. Technol.42: 47-52.

Taschetto, O.M. and Pagliarini, M.S. (1993). Description of a new meiotic abnormality in maize. Maydica 38: 47-50.

Veilleux, R.E. (1985). Diploid and polyploid gametes in crop plants: Mechanisms of formation and utilization in plant breeding. Plant Breed. Rev. 3:253-288. 